\title{
The Traditional Roots of Alimony in the Hungarian Family Law
}

\section{Object and method of the research}

The bill having the title Private Law Code of Hungary (hereinafter referred to as PLC) ${ }^{1}$, presented before the House of Representatives by minister of justice Pál Pesthy on the $1^{\text {st }}$ of March 1928, took a prominent place in the history of the civil law codification in Hungary. Although the bill has never entered into force it nevertheless was of particular significance since it was applied in practice and functioned as customary law referred to as "uncodified code". In my paper the institution of alimony will be discussed in a comparative way in the light of the bill in question and its $19^{\text {th }}$ century antecedents.

The system of marital property law was primarily formed by the judicial practice based on the traditional customary law in Hungary in the $19^{\text {th }}$ century. This system was modified by denominational legal norms pertaining to the marriage bond in so far as marital property law was the pecuniary consequence of rights and duties of a moral kind between the spouses. The late adoption of civil law codification led to the survival of the plurality of legal sources regulating marital property even after the first Hungarian secularized uniform Matrimonial Causes Act (Act 31 of 1894, hereinafter referred to as MA) had come into force as supplement to marriage bond law. This Act regulated only some institutions of property law and as we will see, it did not do it in an exhaustive manner. A legal historian can only try to describe the duality of judicial practice ${ }^{2}$ and statutory law - including the first reading of the bill (General Civil Code, hereinafter referred to

\footnotetext{
${ }^{1}$ Magyarország Magánjogi Törvénykönyve [Private Law Code of Hungary], Budapest 1928.

2 See in the first place T. Fabinyi, A polgári perrendtartás törvénye és joggyakorlata II [The Code of Civil Procedure and its practice II], Budapest 1931; L. Ladányi, Bíráskodás házassági perekben [Jurisdiction in matrimonial cases], Budapest 1910; D. Nagy, A házassági jog és a Kuria gyakorlata [Matrimonial law and judicial practice of the Curia], Budapest 1941.
} 
as GCC) $)^{3}$ and resorting to the help of the comprehensive works of civil law scholars ${ }^{4}$. Judicial practice concerning temporary and final alimony is described on the basis of my own archival research.

\section{The legal effect of marriage on persons}

The legal effect of marriage on persons refer to the rights and duties of a moral nature which spouses enjoy and owe to each other and which originate from their valid matrimonial contract. The moral nature of these rights and duties does not terminate their legal nature since these rights and duties entail pecuniary consequences and thus determine matrimonial property and inheritance law. In legal literature ${ }^{5}$ it was emphasized that the power of the husband similar to manus in Roman law and the German Munt was unknown in Hungarian law both at the time of Werböczy and later. But husband was the "head of the family", which was generally believed to be due to "the nature of marital cohabitation". This position of the husband can explain the fact that alimony - although being an institution of property law - was, in legal literature, dealt with in the area of the legal effects of marriage on persons.

According to the principle established by judicial practice the husband as "the head of the family" fulfils his "spousal (and paternal) obligation" nance to his wife and underage children. In respect of maintenance the wife was taken into consideration in the same way as an underage child. Most Hungarian women had no professional educational background and conducted no gainful activity even in the second part of the $19^{\text {th }}$ century, thus alimony continued to be interpreted as the consequence of the factual circumstances of the time'.

3 A Magyar Általános Polgári Törvénykönyv tervezete, első szöveg [Bill of General Civil Code of Hungary, first draft], Budapest 1900.

${ }^{4}$ See in the first place I. Frank, A közigazság törvénye Magyarhonban [Law of public justice in Hungary], Buda 1845; B. Grosschmid, A Házasság törvény (1894. XXXI. t.-cz.) [The Matrimonial Causes Act (Act 31 of 1894)], vol. 1-2, Budapest 1908; M. Herczeg, Magyar családi és örökösödési jog [Matrimonial and inheritance law in Hungary], Budapest 1885; G. Jancsó, A magyar házassági és házastársi öröklési jog [Matrimonial law and marital inheritance law in Hungary], Budapest 1901; K. Szladits, A magyar magánjog vázlata [The sketch of private law in Hungary], Budapest 1909; G. Zachár, A magyar magánjog alaptanai [Fundamental doctrines of Hungarian private law], Budapest 1912; I. Zlinszky, A magyar magánjog mai érvényben különös tekintettel a gyakorlat igényeire [Hungarian private law in force with special regard to the claims of practice], Budapest 1902.

${ }^{5} \mathrm{~K}$. Szladits, A házastársak közötti személyes jogviszony [Personal legal relation between the spouses], [in:] Magyar jogi lexikon, ed. M. Dezső, vol. 4, Budapest 1903, pp. 118-120; G. Jancsó, A magyar házassági..., pp. 571-573; L. Tóth, A magyar nőkről (Függelék Gide Pál: A nők joga címü müvéhez) [About Hungarian women (Appendix to the book Right of Women of Pál Gide)], Budapest 1887, p. 40 and pp. 400-405.

${ }^{6}$ G. Jancsó, A magyar házassági..., p. 575 and I. Zlinszky, A magyar magánjog..., p. 901.

7 Curia No. 5889/1885, No 9243/1892 and No. 4/1897. When it is not especially denoted see the decisions of the Curia by M. Dezső (ed.): Felsöbiróságaink elvi határozatai. A m. kir. Curia és a kir. táblák elvi jelentöségü döntéseinek rendszeres gyüjteménye [Principal decisions of our superior courts. Systematical collection of decisions of fundamental importance of the Hungarian Royal Curia and the royal courts of appeal], vol. 2-10, Budapest 1883-1901.

${ }^{8}$ Curia No. 6843/1883, see also G. Jancsó, A magyar házassági..., p. 578.

9 G. Jancsó, A magyar házassági..., p. 578. 


\section{Alimony during marriage with the parties' cohabitation}

During marital cohabitation it was the husband's obligation - and the wife could not waive it for the benefit of the husband ${ }^{10}$ - to provide decent maintenance to the family and cover all expenses connected with the matrimony. This obligation was terminated upon the death of the wife since it was linked to her person. Consequently the wife's entitlement did not devolve to her heirs or third parties. Maintenance was "decent" if it complied with the financial situation and social status of the husband. In judicial practice ${ }^{11}$ and also in the $\mathrm{GCC}^{12}$ maintenance basically covered accommodation, food, clothing and intellectual needs. Likewise, the husband had to "cover the medical costs of the treatment of the wife" 13 .

The PLC - in a laconic but logic manner - sets out only three components of the "decent" maintenance (financial situation, earning capacity, and social status) ${ }^{14}$. In the earlier practice "decent" maintenance provided for the covering of all costs of marriage, too. PLC sets two reasonable limits and $\S 98$ of GCC made it more express: on the one hand wife could act for her husband in the name of her husband, within the limits of her husband's financial capacity, but this right to represent could be withdrawn wholly or partly for some serious reasons on the other hand ${ }^{15}$.

The husband provided maintenance to the common household in-kind. The wife could - exceptionally - demand the maintenance in money only if the husband refused to provide it in-kind or if his or his relatives' unbearable conduct made it impossible for her to enjoy this maintenance ${ }^{16}$. The husband could not demand that his wife should contribute to the maintenance of the family from her own property. However, during marriage the husband disposed of and handled her dowry (allatura), which had been given to her by her father, brother or any other person ${ }^{17}$ except the husband for lightening the financial burden of the marriage. Thus the dowry (movable and immovable property and property rights) constituted the property of the wife over which the husband exercised his exclusive beneficial rights. In addition, the wife could let her husband administer her own separate property. She could do it either by an express statement of will or tacitly ${ }^{18}$. The husband was not accountable for the decrease in the separate property of his wife unless stipulated otherwise in the contract, and he did not have to refund it. Thus the income from the separate property was used for covering the expenses of the household. If the husband did not provide decent maintenance to his family and his wife had to secure it from her separate property, she did not have the right to demand its reimbursement

\footnotetext{
${ }^{10}$ Curia No. 476/1898 and I. G. No. 513/1901, explained by J. Bajzáth, Ideiglenes nötartás [Temporary alimony], Jogtudományi Közlöny 1813/52 p. 462.

${ }^{11}$ Curia No. 6843/1882, No. 5889/1885 and No. 7614/1885, explained by G. Jancsó, A magyar házassági..., p. 580 .

12 GCC $96 \S$.

13 Curia No. $3939 / 1884$, No. $1356 / 1896$ and 9243/1892. See the same principle in GCC $96 \S$.

14 PLC 113 \$.

15 PLC $115 \S$.

16 Curia I. G. No. 198/1899, see in Ügyvédek Lapja 1899/32.

17 Act 7 of $188621 \S$.

18 I. Zlinszky, A magyar magánjog..., p. 899.
} 
even if the marriage was terminated, nor could her husband demand from his wife or her heirs the money he had spent on maintenance.

$\mathrm{PLC}^{19}$ changed this traditional custom to a certain extent and so adjusted itself to the requirements of the epoch. Previously it was a natural thing that in legal relation between husband and wife "woman does the housework and aids her husband by her agency in his gainful employment" and consequently "she makes a contribution with her further income to the payment of the household costs". What both in $\mathrm{GCC}^{20}$ and PLC made up a new element was that "she was required to conduct gainful activity when living conditions of the family demanded so". This rule of the "uncodified code" stroke roots in the judicial practice very fast $\mathrm{t}^{21}$ because of the subsidiary character of the aforementioned principle, although maintenance of children and wife remained a task of the husband in the future as well ${ }^{22}$.

\section{Alimony during marriage on occasion of the separation of the parties}

Discontinuing marital cohabitation did not terminate the husband's obligation to maintain his wife since the marriage was not terminated by this discontinuing either. This life situation could occur in four different legal situations. After the entry into force of the uniform state divorce law as independent of denomination of the parties ${ }^{23}$, separation from bed-and-board (separatio a thoro et mensa) as a residue of canon matrimonial law meant a legal solution only for those who wanted to maintain the bond itself either because of their religious conviction or because they hoped to be able to eliminate the causes of the disintegration of the marriage during separation. In the course of my research I examined all the matrimonial cases initiated at the royal court of Pécs between 1895 and 1918, the cases amounting to 1842 . However, I could find only one case of this kind.

After 21 years of cohabitation Mari K. left her husband, András G., whom she had married in 1875 by the rites of the Roman Catholic Church. Three out of their four children had become grown up by then. The irretrievable breakdown of their marriage was caused by the cruelty of the husband. One and a half year after the court had rejected András G.'s divorce petition on the grounds of desertion, Mari K. applied to the royal court for separation from bed-and-board. The court granted separation, declared the husband's fault, granted to the wife the child's custody and ordered the husband to make payments for the support of the child. The husband was also ordered to pay alimony to the amount of $12 \mathrm{Ft}$ per month from the day of the divorce petition i.e. from the $22^{\text {nd }}$ of June 1898 until the death or a new marriage of the woman ${ }^{24}$. The two superior courts upheld the decision of the first instance court in the course of a review initiated ex officio ${ }^{25}$.

19 PLC $116 \S$.

20 GCC $99 \S$.

${ }^{21}$ Curia No. 2033/1928 and No. 5724/1931, explained by D. Nagy, A házassági jog..., p. 171.

22 Curia No. 2604/1929, explained by D. Nagy, A házassági jog..., p. 171.

$231^{\text {st }}$ of October 1895.

${ }^{24}$ Baranya Megyei Levéltár [County Archive of Baranya (hereinafter CAB)] VII/2b II/1898/249 $16219 \mathrm{p} / 1898$.

${ }_{25} \mathrm{CAB}$ VII/2b II/1898/249 544p/1900 and $1861 \mathrm{p} / 1900$. 
Like in the financial matters, thus also with respect to the issue of alimony, separation had the same legal effect as divorce, nevertheless since the bond still existed and matrimony could be restored at any time, in the cases where separation from bed-and-board was sought the court ordered temporary alimony for the period of separation or until the death or a new marriage of the wife.

Secondly, it should be noted that the parties could request the court that it should order them to live separate and apart from bed and table for the period preceding the decision on the suit for nullity or divorce ${ }^{26}$. In such cases the husband had to pay temporary alimony until the closure of the proceedings.

Thirdly, the court could also order separation ex officio in cases for nullity ${ }^{27}$ or when trying to reconcile the parties in a divorce case. In the case of divorce petitions on so called absolute grounds for divorce, courts "usually" ordered separation; or rather the court could only resign from ordering it if there was no hope for reconciliation ${ }^{28}$. In the case of relative grounds for divorce separation was always ordered, even if the parties had lived separately for a long time before filing the divorce petition. The period of separation was 6-12 months under statutory law; however my research shows that judges always applied the shortest, i.e. the six-month period ${ }^{29}$. Temporary alimony was limited to this period of time.

Finally, the wife could demand temporary alimony without initiating separation or divorce proceedings against her husband living apart. The MA - quite obviously - did not cover such a situation. Therefore only the rules established in judicial practice were followed ${ }^{30}$. The provisions of the MA were regarded as the guiding principle when assessing temporary alimony. What accounted for this "contradiction" was the uniform concept of temporary duty as functioning in judicial practice regardless of which of the four above mentioned situation was at stake.

Before the MA had entered into force, the judicial practice acknowledged the claim of the woman against her husband for temporary alimony for the time of the continuing of the proceedings if separation was not due to her fault. Although the divorce law of the MA that emphasized fault principle contained several provisions which could only be interpreted as quasi punishment imposed on the party at fault, temporary alimony did not depend on whether the wife was at fault or whether she was blamed for causing the irretrievable breakdown of the marriage. In fact the issue of fault could not be decided ${ }^{31}$ in a judgment ordering living apart (ex officio for the sake of reconciliation or upon the parties' request for the time of the proceedings $)^{32}$. Thus in such cases the wife was unconditionally entitled to temporary alimony. Contrary to this, the fact that the woman was at fault excluded temporary alimony if the court separated the parties from bed-and-board because separation had the same legal effect as dissolution in respect of financial ar-

${ }^{26}$ MA 72 and $98 \S \S$.

${ }^{27}$ MA 72 \$.

${ }^{28}$ MA $99 \S$.

${ }^{29}$ E.Cs. Herger, A növételtöl az állami anyakönyvvezetőig. A magyar házassági köteléki jog és az európai modellek [From purchase of woman to the public register. Matrimonial law in Hungary and the European models], Budapest-Pécs 2006, pp. 188-189, pp. 217-232.

${ }^{30}$ Curia No. $157 / 1986$.

${ }^{31}$ Curia No. 1306/1899.

32 Curia No. 2805/1897. 
rangements ${ }^{33}$. In the same way the wife at fault could not be granted temporary alimony if she had requested it against her husband living apart without initiating separation or divorce proceedings. Thus temporary alimony was not granted if the woman or the woman as well as her husband could be attributed a fault for the breakdown of their cohabitation, nor could alimony be granted to her if she was blamed for "injurious conduct" while living apart. It is still to be examined what the courts qualified as "injurious conduct".

Although rough treatment of the wife by her husband was usually admissible as a lawful cause of the wife's leaving her husband's house, the following decision shows that the term "usually" made the roughness relative. While taking into consideration the parties' social status and educational background, we may say that "amongst common peasants the fact that the husband slaps his wife twice in the face for talking back is not to be regarded as a cause of such a nature and measure which could justify the woman's leaving her husband's house and living apart". If the woman did not prove that her husband had driven her out of the house and that she had made steps to return to him in vain, she could not demand alimony from her husband ${ }^{34}$.

In 1895 in the opinion of the Curia the degree of "beating the wife" which did not qualify as a criminal offence did not constitute "injurious conduct". At the end of the $19^{\text {th }}$ century in Hungary the position of the husband as the head of the family entailed the entitlement to inflicting light corporal punishment. Such was the position adopted by the superior court whose decisions were authoritative for all other courts of the country. Moreover, as the wife had to follow her husband to his residence, the husband was found to be at fault only if the wife had tried to restore conjugal life in vain after the expulsion. Three years later the Curia also gave the opinion on the "stubborn or over-sensitive" conduct of the wife. In its opinion "injuries of a lesser importance" should be pardoned by the wife "for the sake of maintaining family life", but if she fails to do so, and her "stubbornness" results in the termination of conjugal life, she cannot demand any financial provision from her husband ${ }^{35}$.

Being at fault or not at fault - as condition of temporary alimony - raised principal questions at the time of private law codification, too. In 1914, Miksa Teller, the wellknown lawyer criticized ${ }^{36} \S 31$ at the second reading because it provided for the temporary alimony to woman regardless of whether she had a lawful cause to live apart or not. However the PLC did not regulate the area of divorce law and did not change the fault principle. So it was logical that the PLC turned back to the traditional custom and acknowledged the claim of the woman against her husband for temporary alimony only when she was not at fault ${ }^{37}$.

${ }^{33}$ MA $105 \S$.

${ }^{34}$ Curia No. $10635 / 1895$.

${ }^{35}$ Curia No. 4/1898.

${ }^{36} \mathrm{M}$. Teller, $A$ vétkes nö ideiglenes tartása [The temporary alimony of woman at fault], "Jogtudományi Közlöny" 1914/16, pp. 164-165.

${ }^{37}$ PLC 118 § (1). 


\section{Alimony after the dissolution of marriage}

Before the entry into force of the MA, denominational laws usually considered the obligation of the husband to provide alimony to be terminated upon the dissolution of the bond. In the case of evangelical parties if the wife proved "such facts" which "might justify derogation from this rule", final alimony could be granted ${ }^{38}$. Among the "substantial causes" there were detectable such as the wife's incapability to work because of the husband's behavior or that the wife was impecunious and - although not due to her husband's fault - incapable of working at the same time. However, the general principle was that

the obligation to pay alimony fell on the husband during the existence of the marriage bond, and if the latter happened to be dissolved (in the case of non-Catholic parties) and the financial arrangement was not provided for in the judgment of divorce, the husband would be obliged to pay alimony until the financial arrangement was produced ${ }^{39}$.

Contrary to this, MA created a situation far more favorable for the woman. Each of its drafts ${ }^{40}$ stuck to the position that the husband's obligation arising from his position as the head of the family to maintain his non-faulty ex-wife was not terminated by the dissolution of marriage. The in subsidio entitlement of the non-faulty wife was explained in the ministerial reasoning of the statute by the fact that it was a "law in action in Hungary too", and then it was underpinned by some similar provisions of the ALR, the Code Civil and the $\mathrm{ABGB}^{41}$. Thus the intention of the lawmaker was to maintain the non-faulty woman's social and financial status enjoyed by her during marriage in this way, since "the husband, who caused the dissolution of marriage by his injurious conduct and thus deprived her wife of the financial advantages which she could enjoy in the conjugal life, deserves to be obliged to compensate her for the loss of these advantages ${ }^{42}$ ".

The parties could freely agree on final alimony, the woman could even waive $i t^{43}$. Among the matrimonial cases initiated at the royal court in Pécs between 1895 and 1918 there were annually less than $10 \%$ of the claims and counterclaims which, among other things, requested final alimony. This can only partly be explained by the fact that the financial conditions of the women did not make alimony necessary. It was rather due to the fact that as a result of the fault theory adhered to in the divorce law such a claim could be made only if the woman was the petitioner or she herself requested in the counterclaim that the marriage be dissolved and her husband be found at fault. In the examined 24-year period the wife was found at fault in more than half of the cases (female respondent: $49,5 \%$ + female petitioner: $0,8 \%$ ).

${ }^{38}$ Royal Court of Appeal in Budapest No. 41743/1885, reported by G. Jancsó, A magyar házassági..., p. 599.

${ }^{39}$ Curia No. 1376/1892.

${ }^{40}$ B. Grosschmid, A Házasság..., vol. 2, pp. 738-740.

${ }^{41}$ Ibidem, vol. 2, pp. 738-740.

${ }^{42}$ G. Jancsó, A magyar házassági..., p. 607.

${ }^{43}$ MA 92 §. 
Diagram 1. Matrimonial cases initiated at the royal court in Pecs (1895-1918), N=1 842 cases.

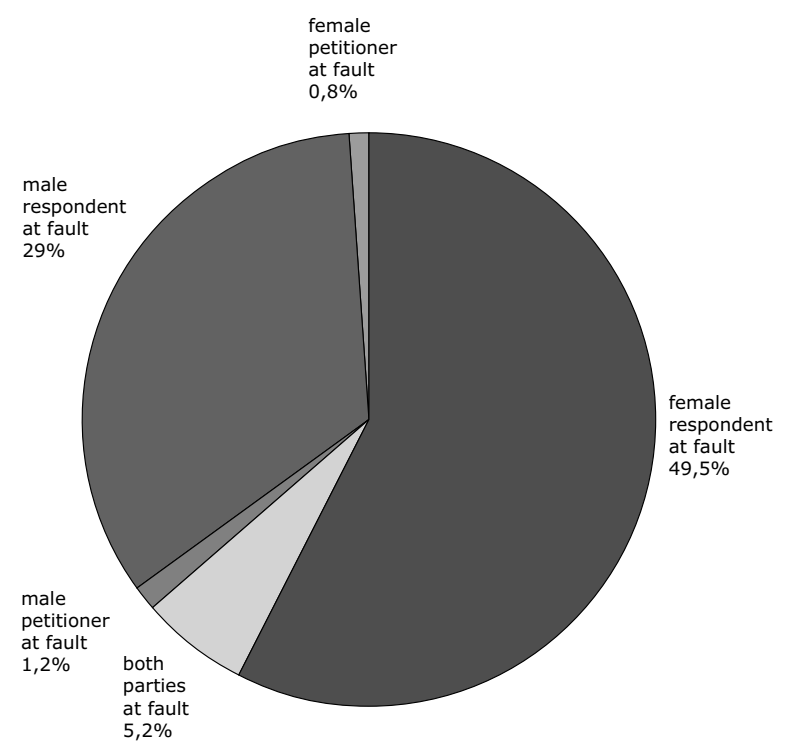

* In the $14,3 \%$ of the matrimonial cases there are no information about the fault of the parties either because these were not divorce cases, or the decision containing the declaration of fault got lost.

Apart from some exceptional years ${ }^{44}$, the pattern was the same in a yearly breakdown and statistical figures showed a similar tendency nationwide. I found one case dated back to the 1912, where the court approved of the counterclaim of a woman that was found at fault and yet was granted alimony.

The marriage contracted between József B. and Anna K. by the rites of the Roman Catholic Church in 1884 was dissolved by the royal court in Pécs in 1912 on the ground of wife's willful and unjustified leaving of her husband. At the same time the court found the respondent (the wife) at fault. The court approved of the respondent's claim for alimony of 600 crowns (contrary to article 90 of the MA) and ordered the petitioner to pay "five crowns monthly in advance as of $1^{\text {st }}$ August 1911, the amount overdue in total within 15 days under penalty of distrait, whilst the other installments at the beginning of each month till the death of the respondent". The reasoning of the court was as follows: the petitioner made no demur to the request of the respondent but offered to pay five crowns per month instead of the payment of 600 crowns. This offer was accepted by the respondent. The fact that the wife deserted the petitioner after two years of cohabitation and 26 years before the filing of the petition made his generosity even more surprising. Thus the court regarded the litigants' right of disposal as stronger than the negative legal consequence attached to fault. There was an unusually short period of time within which the case was settled. 24 days lapsed between filing the petition and the passing of

${ }^{44}$ E.Cs. Herger, $A$ növételtől..., p. 190 and p. 273. 
the judgment. The respondent made no defence and did not object to the dissolution of marriage ${ }^{45}$.

The principle applied in this judgment complied with the practice firmly established in the next years: in 1919, the Curia provided the courts with a possibility to adjudicate on the merits in case of the claim of the woman against her husband for final alimony in the divorce case even under the circumstances when her claim was not based on the statutory law but on the contract of the parties ${ }^{46}$.

If the woman requested alimony in a separate property law action and the claim was based on the statutory law, the ruling of the court in reference to the fault had to be taken into consideration as res judicata even if it had been made under the denominational laws before the adoption of the $\mathrm{MA}^{47}$. Whenever the claim was based on a marriage contract the fault principle was of no importance.

Alimony - for practical purposes - had to be paid in cash and usually in advance, in monthly installments. However derogation was possible in case of the persons engaged in agriculture and manufacturing industries ${ }^{48}$. The alimony imposed could be increased if at first it was assessed at a low level due to the husband's financial status which later improved. It could also be increased if an income of the wife was lost through no fault of her ${ }^{49}$. In case of the decrease or cancellation of the alimony the judicial practice has been changed after 1895 . This meant that after the entry into force of the MA the alimony imposed could not be decreased or cancelled in the practice of the courts ${ }^{50}$ because the MA did not contain provisions in this regard. Based on the opinion of our eminent private legal expert the courts followed this practice because the opposite practice might have made the not-at-fault wife's financial status unstable. Therefore the question of cancellation of final alimony was reflective of the situation in which the regulation of statutory law (or rather, the silence of the regulation about this issue) contradicted the earlier customary law. For a long time the statutory law regulation was interpreted as a prohibitory regulation.

This interpretation was changed ${ }^{51}$ after the entry into force of the Code of Civil Procedure $^{52}$. The new interpretation was based on the general principle of article 413 of the Code, which provided for possibility of altering the content and the measure of an imposed service (in this case alimony) if the circumstances had been radically changed. This solution meant the adoption of standpoint of the contemporary legal experts ${ }^{53}$. Therefore, no tasks remained for the PLC to regulate the question of the final alimony and this is why the PLC left the crystallized legal practice untouched for a long time.

${ }^{45} \mathrm{CAB}$ VII/2b II/1912/255 10612p/1912.

${ }^{46}$ Curia P. III No. 1009/1919, explained by Tihamér Fabinyi, A polgári..., p. 159.

${ }^{47}$ G. Jancsó, A magyar házassági..., p. 605.

${ }^{48}$ Ibidem, p. 608.

${ }^{49} \mathrm{MA} \S 91$.

${ }^{50}$ G. Jancsó, A magyar házassági, p. 610.

${ }^{51}$ Curia P. III No. 2666/1916, explained by D. Nagy, A házassági jog..., p. 266.

${ }^{52}$ Act 1 of 1911, entered into force in 1915.

${ }^{53}$ See for example Béla Malonyai, Végleges nötartás felemelése és leszállitása [Increase and decrease of final alimony], Jogtudományi Közlöny 1918/16 pp. 125-127. 


\title{
The Traditional Roots of Alimony in the Hungarian Family Law
}

\author{
Summary
}

The paper discusses the extent to which the $19^{\text {th }}$ century regulations of alimonies as awarded within the frame of matrimonial relationships had an impact on the formation of claims of alimony as found in the Hungarian Code of Private Law of 1928. The paper discusses the alimony as paid to one of the spouses at the time when the matrimonial tie was still continued but also when the alimony was granted as a temporary device and also when it was awarded after the divorce decree had been granted. 